\section{Sexually transmitted diseases in Latin America and the Caribbean}

\author{
Antonio Carlos Gerbase, ${ }^{1}$ \\ Cristiana Toscano, ${ }^{1}$ Silvia Titan, ${ }^{1}$ \\ Paloma Cuchí, ${ }^{2}$ Roxane \\ González-Salvatierra, ${ }^{3}$ \\ and Fernando Zacarías ${ }^{3}$
}

Sexually transmitted diseases (STDs) have long been known for their great impact on health. In 1995, there were an estimated 333 million new cases of curable STDs among adults around the world (1). The prevalence of STDs in many developing countries, including those of Latin American and the Caribbean (LAC), is extremely high. In the AIDS era there is an urgent need to adequately control and manage these diseases.

A delay in diagnosing and treating STDs can lead to chronic complications and irreversible sequelae. Women and children suffer the main consequences. In women, the most serious consequences are acute and chronic pelvic inflammatory diseases, infertility, ectopic pregnancy, and cervical cancer. Infection during pregnancy may cause spontaneous abortion, stillbirth, prematurity, low birthweight, congenital syphilis, and ophthalmia neonatorum (2).

Controlling STDs is also important because of their relationship with HIV transmission. Several studies have shown that both ulcerative and nonulcerative STDs facilitate HIV transmission (3-16). STD prevention can be an important tool in controlling the spread of HIV. For example, in a community-based, randomized trial in the Mwanza administrative region of Tanzania, improved STD treatment and control resulted in a $42 \%$ reduction in HIV incidence (17).

LAC countries need to have more data regarding the magnitude of STDs. Syphilis prevalence among pregnant women provides a good basis to extrapolate to the general population. Syphilis, however, is the least prevalent of the classical STDs and so is an indicator of minimum (lower limit) STD prevalence. Even given that, the serious magnitude of STDs in Latin American and the Caribbean can be seen from syphilis prevalence among pregnant women, which in 1991 ranged from $1.3 \%$ in Honduras to $6.3 \%$ in Paraguay (1).

A variety of ecological and behavioral determinants influence the emergence and spread of STDs (18). The rate of spread is directly determined by the average risk of infection per exposure, or efficiency of transmission; the average rate of sexualpartner change within a population; and the average duration of the infectious period for individuals with STDs (19). Among other factors contributing to the high incidence and prevalence of STDs in Latin American and the Caribbean are a lack of knowledge of STDs, the structure of health services 
in the LAC countries, self-medication, and antimicrobial resistance.

Demographically, the LAC countries are characterized by a recent change in the pyramid of age distribution (21). While birth rates have remained high, child mortality has been declining progressively due to the success of immunization programs, the use of oral rehydration solutions to treat diarrhea, and improved care for acute respiratory infections $(18,21,22)$. These trends have led to increases in the number of teenagers and young adults, among whom STDs are concentrated. High rates of urbanization and migration increase the male population in large cities. The rate of change of sex partners is higher for men than for women, and men are more likely than women to engage in casual or commercial sex (18).

Other factors have greatly extended the duration of time during which premarital intercourse can occur. Traditional religious and moral codes in Latin America and the Caribbean encouraged early marriage, monogamy, and multiple births. However, these norms are no longer absolute. Menarche is occurring earlier in urban areas than in rural areas, sexual maturation is happening at an earlier age, and more young people are postponing marriage to a later point in life (18).

STD data are scarce and problematic in Latin American and the Caribbean, and wide variations in socioeconomic, cultural, and behavioral factors make comparisons difficult from country to country.

Most of the LAC countries have passive STD surveillance systems. Such systems, however, yield unreliable information since their estimates depend on the extent to which patients seek health care, the intensity of diagnosis, and the quality of reporting. STD surveillance is further complicated by the diseases' natural history. A large number of asymptomatic infections occur with STDs. Only part of the symptomatic population seek health care and even a smaller number of cases are reported (2).

A better alternative for assessing prevalence is etiologic (laboratory) diagnosis on a screened population without STD symptoms, such as pregnant women attending antenatal care, new military recruits, or blood donors. There are limitations with any of these populations, and extrapolations to the general population may lead to errors. However, so far, pregnant women have been the single most important source of information on groups with a low risk for STDs, including HIV.

Assessing incidence is even more difficult. As will be discussed later, an approximation can be calculated by dividing prevalence by the duration of disease. In addition, some indication of incidence trends can come from the reporting from sentinel sites of such acute and self-limited STD syndromes as urethral discharge and genital ulcers.

Another key strategy for STD surveillance is the evaluation of such high-risk groups as sex workers, men who have sex with men, and intravenous drug users. These estimates can provide early-warning signals for the general population.

There is an urgent need to improve STD surveillance and prevention in the LAC nations. This paper intends to help in that effort by reviewing relevant STD prevalence and incidence data and by estimating the 1996 prevalence and incidence of gonorrhea, syphilis, chlamydia, and trichomoniasis in Latin America and the Caribbean.

\section{METHOD}

Data for this paper were collected by searching in a number of sources, including:

- The MEDLINE and LILACS computerized bibliographic databases, to obtain articles published in English, French, Spanish, and Portuguese from 1982 through October 1997 concerning the prevalence and incidence of syphilis, gonorrhea, trichomoniasis, chancroid, and chlamydial infection

- Abstracts and posters from 1982 through 1995 at the worldwide International Conference on AIDS (ICAIDS) meetings, the ICAIDS in Africa conferences, the ICAIDS in Asia and the Pacific meetings, and the international meetings of the International Society for STD Research

- Abstracts and posters presented during the International Congress of Sexually Transmitted Diseases, held in Seville, Spain, 19-22 October 1997

- World Health Organization (WHO) country files for AIDS and STDs, which contain unpublished documents, confidential information, and travel reports from WHO staff members

For the STD prevalence estimates, prevalence studies of different population groups were considered. When possible, data from pregnant women were utilized since such information provides the best approximations to the general population. Prevalence for 1996 was calculated using midyear population estimates of persons from 15 to 49 years old.

We estimated the duration of symptomatic and asymptomatic STDs among persons who are treated and those who remain untreated, by sex, as well as the percentage of asymptomatic STDs, by $\operatorname{sex}(1)$.

Basing our work on health assessments for the LAC countries and discussions with representatives from the various nations, we estimated rates 
of treatment, by sex, for symptomatic and asymptomatic infections. We then estimated the weighted average duration of infection, by sex and by disease. We did this by multiplying the estimated duration of infection by the percentage of symptomatic and asymptomatic persons and by the rates of treatment and nontreatment. We then added these weighted averages of duration of infection for the four different groups (syphilis, gonorrhea, chlamydia, and trichomoniasis) to enable us to calculate incidence rates by sex. This was done by dividing the adult prevalence estimate for the LAC region by the estimated regional weighted average duration of infection. We then calculated the total number of new cases, per year, using the 1996 midyear LAC regional population estimates for adults (15-49 years).

\section{THE MAGNITUDE OF STDS IN LATIN AMERICA AND THE CARIBBEAN}

\section{Syphilis}

Despite its decrease in developed countries, syphilis is still an important STD in developing countries because of its complications and its high rates of infection. Further, syphilis is a disease that can be successfully controlled by relatively easy public health measures.

For the LAC region as a whole, however, it is difficult to make broad generalizations about syphilis. There are many socioeconomic disparities among the various nations and within different regions of the same country, even though the coun- tries in Latin America and the Caribbean share many cultural and demographic characteristics.

The following subsections look at data for various populations within the LAC region, as well as trends over time in several nations.

\section{Pregnant women}

In recent surveys, syphilis prevalence among pregnant women has ranged widely, as can be seen in Figure 1.

Evidence for some of the general trends relating to STDs in Latin America and the Caribbean, such as the higher prevalence rates in urban areas, can be seen with the syphilis data for pregnant women (23-26). In Paraguay, for example, a 1991 study of 1000 rural and urban pregnant women found a $6.0 \%$ positive rate among the urban women and a $2.5 \%$ rate among rural women (27).

\section{High-risk population groups}

In some high-risk population groups, such as sex workers and prison inmates, prevalence rates are often much higher than with pregnant women. With male prison inmates, for example, seropositivity values of $18.4 \%$ were found in Brazil and of $5 \%$ in the Dominican Republic $(29,30)$. Also in the Dominican Republic, serologic evidence of syphilis was found in $7.3 \%$ of the men who have sex with men (30). Among injecting drug users in the city of Santos, Brazil, there was a $34 \%$ syphilis prevalence rate (31).

Studies of sex workers in the LAC countries have found various prevalence rates for syphilis. They have included: 7\% in Panama (1987) (32), 17\% in Honduras in (1991) (33), 17.9\% in Bolivia (1992)

FIGURE 1. Prevalence of syphilis in pregnant women, Latin America and the Caribbean, 1990-1997

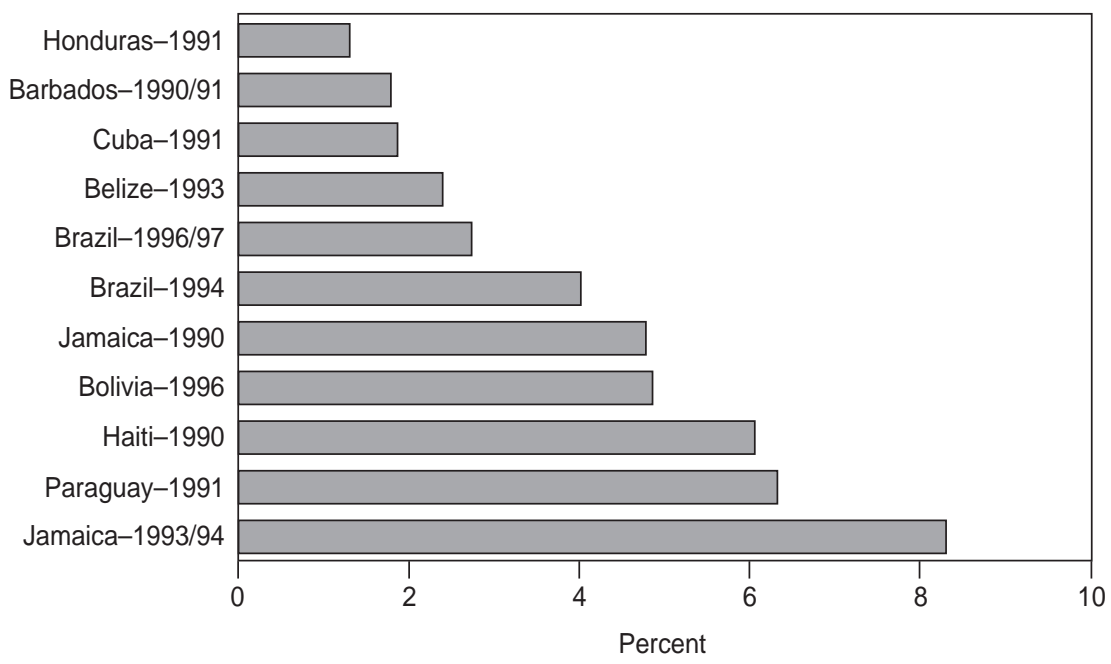


(34), $19.6 \%$ in the Dominican Republic (1992) (35), and 29\% in Santos, Brazil (1990) (36).

Those differences also exist within individual countries. For example, data from Sergipe, a state in the northeast of Brazil, differ greatly from those for Santos, a major port city in the southeast of Brazil. While a syphilis prevalence rate of $29 \%$ is seen among sex workers in Santos, a $47.5 \%$ rate is present is Sergipe (37). These two areas represent distinctive socioeconomic patterns within Brazil. Sergipe is a poor state with late diagnosis and treatment of syphilis, factors which increase the duration of infectiousness and spread of the disease. In contrast, in the Santos region, better primary health care and better education on STDs over the last decade have improved health seeking and accessibility and possibly contributed to the lower prevalence rate.

A second Brazilian study again points out the possible impact of socioeconomic differences. In the state of São Paulo, screening of 600 female sex workers in the cities of São Paulo, Santos, and Campinas found an overall $45 \%$ prevalence rate for syphilis. Those with a lower socioeconomic status were more likely than those with a higher socioeconomic status to be infected, $66 \%$ versus $24 \%$ (38).

Mexico is another country where studies among sex workers have found varying syphilis prevalence levels. In 1990, 23.7\% of 1386 sex workers in four Mexican states had a reactive syphilis test (39). In 1993, testing of 826 sex workers in Mexico City showed a prevalence rate of $6.4 \%$ (40). Among 3100 female sex workers who were tested for syphilis at an AIDS clinic during 1992 and 1993, an $8.2 \%$ prevalence rate was found (41). Different patterns of sex work are associated with different risks of STD infection. That study of 826 sex workers in Mexico City found syphilis prevalence rates of $1.3 \%$ for massage parlor workers, $4.4 \%$ for bar girls, and $9.6 \%$ for streetwalkers.

\section{Blood donors}

Recent studies have found syphilis prevalence among blood donors varying from $0.93 \%$ in $\mathrm{Ar}$ gentina (42) to $5.2 \%$ in Jamaica (43). Studies in Honduras (44), Haiti (45), and in Brazil (46) during the 1980s and the 1990s have found decreasing syphilis prevalence rates among blood donors (Figure 2). These declines may be due to a variety of factors, including stricter preselection of donors through interviews and the rejection of potential donors considered to have high-risk sexual behavior.

\section{Trends over time}

Apparent changes in prevalence rates over time may or may not be real, as can be seen from the cases of Jamaica and Chile. In Jamaica, reported cases of congenital syphilis, in absolute numbers, rose steadily, with 5 cases in 1985, 15 in 1986, 36 in 1987, 46 in 1988, and 51 in 1989 (43). Prevalence among blood donors increased from 1985 to 1987, declined slightly in 1988, and again increased in 1989. These trends may represent a real increase in syphilis incidence and prevalence in the country. In Chile, reported cases fell from 1986 to 1987, but then generally rose over the next five years (Figure 3) (47). The increase between 1987 and 1992 may have been an apparent one due to more-adequate reporting, or it may have been a real one caused by certain demographic, sociopolitical, and economical factors.

\section{Gonorrhea}

Despite its being a common disease, few LAC countries have regular screening programs for gon-

FIGURE 2. Syphilis prevalence trends among blood donors in Brazil, Haiti, and Honduras, 1986-1993

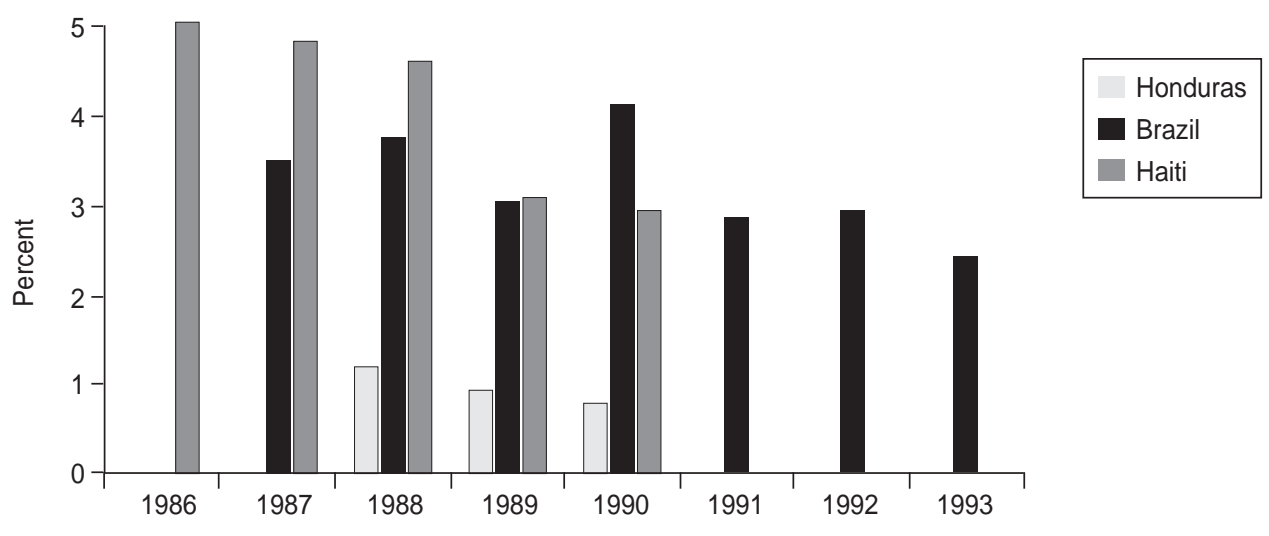


FIGURE 3. Reported incidence of syphilis, Chile 1986-1992

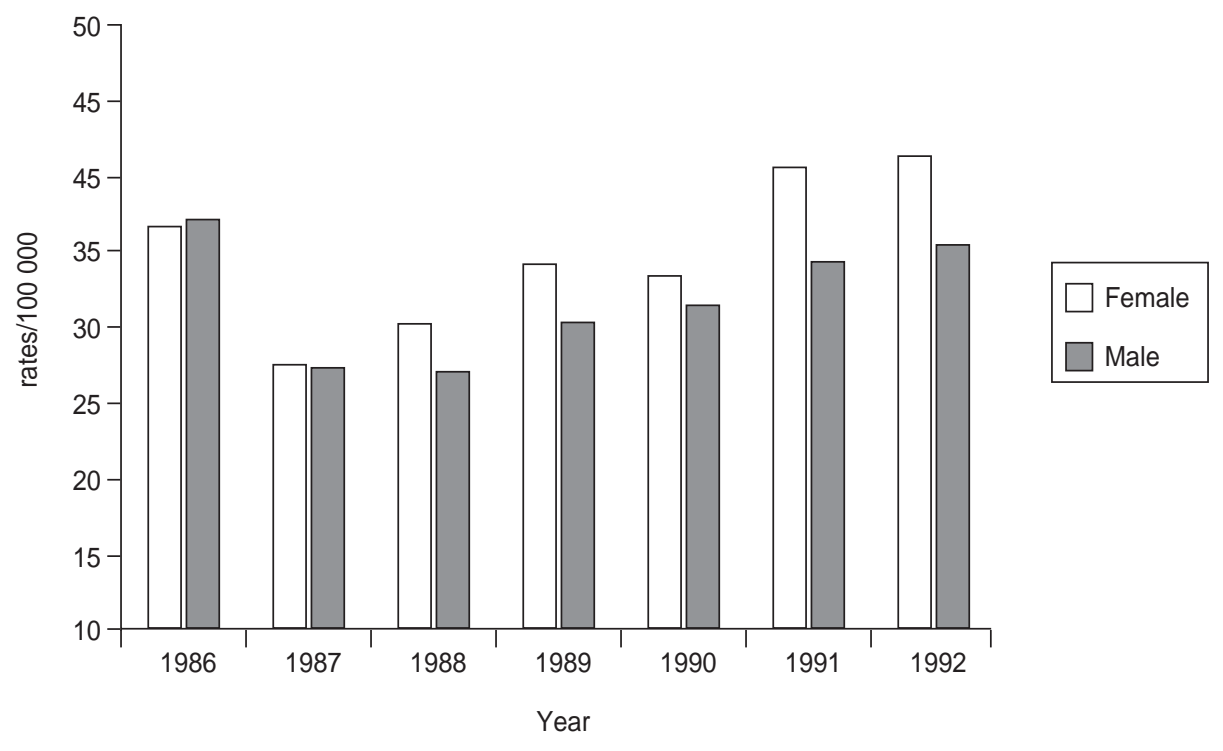

orrhea, and reporting usually does not reflect the true epidemiological situation in a country. The fact that chlamydial and gonococcal infections frequently coexist (48) makes this circumstance even more serious.

As with other STDs, a wide range of gonorrhea prevalence rates have been found in recent years in the LAC countries. Antenatal care attendants in Nicaragua presented a gonorrhea prevalence rate of $1.3 \%$ in 1993 (49). In 1988 the prevalence of gonorrhea among adolescent pregnant women in Chile was 1.0\% (51). In Barbados in 1995 gonorrhea prevalence among pregnant women attending antenatal care was of $0 \%$ (52). In Niterói, Brazil, $5 \%$ of the women attending the STD section of a hospital for the first time tested positive for gonorrhea $(53,54)$.

Rates tend to be high among sex workers in the LAC region, with recent studies finding prevalence rates ranging from $7.2 \%$ in Nicaragua (49) to $25 \%$ in Honduras (50). In Mexico in 1990, an 11.5\% gonorrhea prevalence was found among 1386 sex workers (40). In a 1993 study that included 826 sex workers, 3.7\% tested positive for gonorrhea (41).

As was described earlier with syphilis, studies in various countries have found that rates of gonococcal infection can vary for different patterns of sex work. In Panama, for example, streetwalkers had a $31 \%$ prevalence rate, while cabaret entertainers had a $3 \%$ rate (58). A similar pattern has been observed in Mexican studies (39). In 1994, testing of 662 sex workers showed a gonorrhea prevalence of $0 \%$ for massage parlor workers, $0 \%$ for bar sex workers, and $5.9 \%$ for streetwalkers. These results are likely related to the fact that streetwalkers belong to a lower socioeconomic class. Given that in many developing countries, STD control programs are dominated by clinically oriented approaches and there are few primary prevention activities, these streetwalkers are less likely to seek and obtain quality medical assistance and to buy condoms, and they tend to have a greater number of sexual partners in order to increase their income.

\section{Trends over time}

Some LAC countries have had apparent declines in gonorrhea rates, while others have shown increases. For example, in Costa Rica the reported incidence of gonorrhea showed steady declines between 1986 and 1991, among both men and women (59), and similar decreases were observed in Chile between 1986 and 1992 (60).

In contrast, in Jamaica rates of reported gonorrhea had been going down but then experienced a sharp increase. Incidence fell from 475 per 100000 in 1987 to $350-360$ per 100000 for $1988-1989$ but climbed back up to 500 per 100000 in 1991 (61). This seeming trend should be viewed with caution since it could be due to better surveillance and reporting systems rather than being a real increase.

\section{Trichomoniasis}

Limited epidemiological data is available on trichomoniasis even though it is one of the most common STDs and diagnosis is simple and treatment is effective. 
Prevalence studies with pregnant women show diverse rates, ranging from $2.1 \%$ in Brazil in 1991-1993 (53) and 3.6\% in Barbados (52) to 8\% in Nicaragua in 1993 (49) and 27.5\% among pregnant rural Chilean women in 1989 (55).

In Barbados, symptomatic women showed a trichomoniasis prevalence of $11.4 \%$ (52).

In Cuernavaca, Mexico, 405 sexually active women attending a hospital for a regular gynecological consultation had a $1.7 \%$ positive rate for Trichomonas vaginalis infection (56). In another Mexican study, screening of 800 women with an active sexual life attending a cervical and uterine cancer detection service found a $3.13 \%$ trichomoniasis prevalence rate (57).

\section{Chlamydia}

Chlamydial infection is a common STD. Among the most common risk factors for it are being young, having more than one sex partner, having a new partner, being single, being heterosexual, using hormonal contraception, not using barrier contraception, and having gonorrhea, a previous chlamydial infection, or cervical ectopy (1).

Chlamydial infections have high asymptomatic rates in women and men, making clinical diagnosis difficult. Diagnostic methods are costly, and the most sensitive tests are generally not available in the LAC countries.

There are numerous prevalence studies of chlamydial infection in different population groups in the LAC countries, with the majority of the studies using serological diagnostic tests. However, the results of these surveys need to be carefully analyzed since most serological tests are not specific enough for epidemiological purposes (62). For example, in Barbados, a discrepancy between serology and enzyme immunoassay (EIA) was demonstrated both in pregnant women and in a group of women attending an STD service (52). The former group had a positive rate of $74.5 \%$ with serology, compared with $23.6 \%$ with EIA. The second group had a $60 \%$ positive serological rate against $14 \%$ with EIA.
Below we present data from a number of countries, obtained by testing methods that included culture, "Microtrak" direct fluorescent antibody (DFA) testing, direct immunofluorescence (DIF), and immunoenzimatic assay.

A prevalence study of chlamydial infection among pregnant women in Brazil, using DIF, showed rates of $21.5 \%$ for women 20 years and older, while adolescents (14-19 years) had a prevalence rate of $41.5 \%$ (63). These results illustrate the association of young age with chlamydial infection. Another study in Brazil, among low-income women attending urban public health centers in Rio de Janeiro from 1993 to 1995, showed a chlamydial infection prevalence of $22.8 \%$, using the Microtrak diagnostic method (65).

In Mexico chlamydia prevalence among sexually active women, diagnosed by culture, was approximately $4 \%$ (66). In a study of men who have sex with men, a $4.3 \%$ prevalence was found, using immunofluorescence detection with urethal exudate samples (67).

In Nicaragua, prevalence of cervical chlamydia infection, based on positive DFA and/or polymerase chain reaction, varied from $2 \%$ among routine clinic attendees aged 35 or older to $8 \%$ among adolescent clinic attendees (68).

In Peru, using a microimmunofluorescent assay, rates of $2.8 \%$ for men and $14.1 \%$ for women were found among persons seeking preemployment or routine annual worker health certification (20).

Asymptomatic sexually active patients attending health service in Uruguay had urine samples tested with ligase chain reaction for Chlamydia trachomatis. The female population had a prevalence rate of $3.4 \%$, compared to $2.4 \%$ for men (64).

\section{ESTIMATES}

As described earlier, the data gathered in this review were analyzed in order to provide estimates of prevalence and incidence for the main bacterial STDs in Latin America and the Caribbean. Those estimates are summarized in Tables 1, 2, and 3.

TABLE 1. Estimated STD prevalence (\%), persons 15-49 years old, Latin America and the Caribbean, 1996

\begin{tabular}{|c|c|c|c|c|c|c|c|}
\hline \multicolumn{2}{|c|}{ Syphilis } & \multicolumn{2}{|c|}{ Gonorrhea } & \multicolumn{2}{|c|}{ Chlamydia } & \multicolumn{2}{|c|}{ Trichomoniasis } \\
\hline $\operatorname{Men}^{\mathrm{a}}$ & Women $^{\mathrm{b}}$ & Men $^{\mathrm{a}}$ & Women ${ }^{b}$ & Men $^{a}$ & Women $^{b}$ & Men ${ }^{\mathrm{a}}$ & Women ${ }^{b}$ \\
\hline 5.80 & 7.20 & 6.30 & 10.80 & 25.20 & 42.00 & 8.40 & 84.00 \\
\hline
\end{tabular}

a For men the average duration (years) of the STDs is: syphilis, 1.27; gonorrhea, 0.23 ; chlamydia, 0.63 ; and trichomoniasis, 0.12 .

${ }^{b}$ For women the average duration (years) of the STDs is: syphilis, 1.27; gonorrhea, 0.37; chlamydia, 1.03; and trichomoniasis, 1.21 . 
TABLE 2. Estimated yearly incidence rates per 1000 for STDs among population 15-49 years old, Latin America and the Caribbean, 1996

\begin{tabular}{cccc}
\hline \multicolumn{4}{c}{ STD } \\
\hline Syphilis & Gonorrhea & Chlamydia & Trichomoniasis \\
\hline 5.07 & 28.44 & 40.18 & 70.85 \\
\hline
\end{tabular}

TABLE 3. Estimated new STD cases (in thousands) among persons $15-49$ years old, Latin America and the Caribbean, 1996

\begin{tabular}{lccccr}
\hline & \multicolumn{5}{c}{ STD } \\
\cline { 2 - 6 } Country/subregion & Syphilis & Gonorrhea & Chlamydia & Trichomoniasis & Total \\
\hline Andean & 263 & 1478 & 2088 & 3682 & 7511 \\
Southern Cone & 145 & 812 & 1147 & 2022 & 4124 \\
Brazil & 439 & 2464 & 3481 & 6139 & 12524 \\
Central America & 79 & 443 & 626 & 1104 & 2252 \\
Mexico & 242 & 1359 & 1920 & 3386 & 6908 \\
Latin Caribbean & 79 & 443 & 626 & 1104 & 2252 \\
English Caribbean & 20 & 115 & 162 & 286 & 584 \\
$\quad$ Total LAC & 1268 & 7114 & 10051 & 17722 & 36155 \\
\hline
\end{tabular}

The strategy to limit STD infections and therefore reduce the incidence of HIV infection should include efforts to change sexual behavior, encourage persons to seek health care, and provide early prognosis and treatment facilities for STD patients and their partners. It is hoped that this paper helps in those efforts by providing new information on STD prevalence and incidence in Latin America and the Caribbean.

\section{SINOPSIS}

\section{Enfermedades de transmisión sexual en América Latina y el Caribe}

Las enfermedades de transmisión sexual (ETS) constituyen un problema de salud pública con importantes consecuencias y secuelas que incluyen la enfermedad inflamatoria pélvica, la infertilidad, el carcinoma cervical y los desenlaces adversos del embarazo. En la última década, la estrecha asociación entre la presencia de ETS y el aumento del riesgo de transmisión sexual del virus de la inmunodeficiencia humana ha renovado el interés por la prevención y control de las ETS. Sin embargo, en América Latina y el Caribe, la información epidemiológica sobre la magnitud del problema de las ETS es escasa y, en general, está limitada a un pequeño número de estudios y a datos oficiales incompletos de los países de la zona. Tras una cuidadosa revisión de la literatura y un análisis de los datos que posee la Organización Mundial de la Salud sobre cada país, hemos estimado la prevalencia e incidencia en América Latina y el Caribe de cuatro ETS curables (sífilis, gonorrea, infección por clamídias y tricomoniasis) en hombres y mujeres de 15 a 49 años de edad. Para ello se utilizaron parámetros tales como la duración de la infección, la estimación de los pacientes tratados frente a los no tratados y los datos de población. En 1996, el número estimado de casos en América Latina y el Caribe fue de 1,3 millones para la sifilis, de 7,1 millones para la gonorrea, de 10,0 millones para las infecciones clamidiales y de 17,7 millones para la tricomoniasis. Con una cifra estimada total que, en el mejor de los casos, es superior a 36 millones de casos anuales, las ETS tratables parecen constituir un importante problema de salud pública en la zona. 
1. World Heath Organization/Global Program on AIDS. Global prevalence and incidences of selected curable sexually transmitted diseases: overview and estimates. Geneva: WHO; 1995. (Publication WHO/GPA/STD 95.1)

2. Holmes KK, Mårdh PA, Sparling PF. Sexually transmitted diseases. 2nd ed. New York: McGraw-Hill; 1990.

3. Laga M, Nzila N, Goeman J, et al. The interrelationship of sexually transmitted diseases and HIV infection: implications for the control of both epidemics in Africa. AIDS 1991;5 Suppl 1:S55-63.

4. Stamm WE, Handsfield HH, Rompalo $\mathrm{AM}$, et al. The association between genital ulcer disease and acquisition of HIV infection in homosexual men. JAMA 1988;260(10):1429-1433.

5. Kreiss JK, Coombs R, Plummer F, et al. Isolation of human immunodeficiency virus from genital ulcers in Nairobi prostitutes. J Infect Dis 1989;160(3): 380-384.

6. Plummer FA, Wainberg MA, Plourde P, et al. Detection of human immunodeficiency virus type 1 (HIV 1) in genital ulcer exudate of HIV-infected men by culture and gene amplification. J Infect Dis 1990;161:810-811.

7. Laga M. Epidemiology and control of sexually transmitted diseases in developing countries. Sex Trans Dis 1994;21(2 Suppl): S45-50.

8. Cameron DW, D'Costa LJ, Maitha GM et al. Female to male transmission of human immunodeficiency virus type 1: risk factors for seroconversion in men. Lancet 1989;2(8660):403-407.

9. Plummer FA, Simonsen JN, Cameron DW, et al: Cofactors in male-female sexual transmission of human immunodeficiency virus type 1. J Infect Dis 1991;163: 223-239.

10. Darrow WW, Echenberg DF, Jaffe HW et al. Risk factors for human immunodeficiency virus (HIV) infections in homosexual men. Am Journ Publ Health 1987; 77(4):479-483

11. Plourde PJ, Pepin J, Agoki E, et al. Human immunodeficiency virus type I seroconversion in women with genital ulcers. J Infect Dis 1994;170(2):313-317.

12. Simonsen JN, Cameron DW, Gakinya $\mathrm{MN}$, et al. Human immunodeficiency virus infection among men with sexually transmitted diseases. N Engl J Med 1988;319(5):274-278.

13. Simonsen JN, Plummer FA, Ngugi EN, et al. HIV infection among lower socioeconomic strata prostitutes in Nairobi. AIDS 1990;4(2):139-144.

14. Laga M, Manoka A, Kivuvu M, et al. Non-ulcerative sexually transmitted diseases as risk factors for HIV-1 transmission in women: results from a cohort study. AIDS 1993;7:95-102.

15. Hayes RJ, Schulz KF, Plummer FA. The cofactor effect of genital ulcers on the per-exposure risk of HIV transmission in sub-Saharan Africa. J Trop Med Hyg 1995;98:1-8.

16. Pepin J, Plummer FA, Brunham RC, et al. The interaction of HIV infection and other sexually transmitted diseases: an opportunity for intervention. AIDS 1989:3:3-9.

17. Grosskurth H, Mosha F, Todd J, et al. Impact of improved treatment of STD on HIV infection in rural Tanzania: randomised controlled trial. Lancet 1995; 346:530-536.

18. Holmes KK. Human ecology and behavior and sexually transmitted bacterial infections. Proc Natl Acad Sci USA 1994;91 (7):2448-2455.

19. Anderson RM, May RM. Epidemiological parameters of HIV transmission. Nature 1988:333(6137):514-519.

20. Sánchez J, Gotuzzo E, Escamilla J, et al. Gender differences in sexual practices and sexually transmitted infections among adults in Lima, Peru. Am J. Public Health 1996; 86(8):1098-1107.

21. Goeman J, Meheus A, Piot P, et al. L'épidémiologie des maladies sexuellement transmissibles dans les pays en développement a l'ère du Sida. Ann Soc Belg Med Trop 1991;71(12):81-113.

22. Aral SO, Holmes KK. Sexually transmitted diseases in the AIDS era. Sci Am 1991;264(2):62-69.

23. Amaral E, Faundes A, Gonçales NS, et al. Prevalence of HIV and Treponema pallidum infections in pregnant women in Campinas and their association with socio-demographic factors. Rev Paul Med 1996;114(2):1108-1116.

24. Serrano LV, Miranda AE, Oliveira CA, et al. Prevalence of syphilis in pregnant women attending a university hospital in Vitoria, Brazil. Abstract P.830, International Congress of Sexually Transmitted Diseases. Seville, Spain, 19-22 October 1997.

25. Guinsburg R, dos-Santos AM, Leal DV, et al. Sorologia positiva para sífilis no periodo neonatal: prevalência em maternidade de nível secundário; associação com fatores de risco maternos e com sorologia positiva para HIV-I. Rev Assoc Med Bras 1993;39(2):100-104.

26. Douglas KG, Behets F, Brathwaite A, et al. Syphilis in pregnant women: an evaluation of Victoria Jubilee Hospital, Kingston, Jamaica. Abstract P. 818, International Congress of Sexually Transmitted Diseases. Seville, Spain, 19-22 October 1997.

27. Vera E, Cabral M, Jimenez R, Kiefer R Cabello A, Cabral B. The first study of HIV, HBV and syphilis in pregnant women in Paraguay. International Conference on AIDS, 19-24 July 1992. (Abstract No. PoC 4068).

28. Ducós J, Ramirez A, Péres J, Florencio M, Perdomo C. HIV and syphilis among inmates of the Dominican Republic. IX
International Conference on AIDS, Berlin, 6-11 June 1993. (Abstract No. PO C02 2601)

29. de Andrade AL, Martelli CM, Sousa LC de Sousa MA, Zicker F, et al. Seroprevalence and risk factors for syphilis in prisoners in Goias, Brazil. Rev Inst Med Trop Sao Paulo 1989;31(3):177-182.

30. Tabet SR, de Moya EA, Holmes KK, et al. Sexual behaviors and risk factors for HIV infection among men who have sex with men in the Dominican Republic. AIDS 1996:10(2):201-206.

31. de Carvalho HB, Mesquita F, Massad E, et al. HIV and infections of similar transmission patterns in a drug injectors community of Santos, Brazil. J Acquir Immune Defic Syndr Hum Retrovirol 1996; 12(1):84-92.

32. Reeves WC, Quiroz E. Prevalence of sexually transmitted diseases in high-risk women in the Republic of Panama. Sex Transm Dis 1987;14(2):69-74.

33. Vengas VS, Madrid JP, Lorenzana J, et al. Human immunodeficiency virus infection and syphilis in Hondurian female prostitutes. Int J STD AIDS. 1991 Mar-Apr; 2 (2): 110-113.

34. Lewis J et al. RPR card testing among commercial sex workers in La Paz, Bolivia. X Meeting of the International Society for STD Research, Finland 1993.

35. Difo $C$ et al. Comparación de los resultados del VDRL con los obtenidos por FTA-Abs en trabajadoras sexuales que acudieron al centro de transmisión sexual de Puerto Plata. Acta Med Domin 1992;14(3):90-93.

36. Araujo AC, Fortuna ES. Seropositivity to Chlamydia trachomatis in prostitutes: relationship to other sexually transmitted diseases. Presented at the Annual Meeting of the "Federação das Sociedades de Biologia Experimental," Caxambu, MG, Brazil. 1990.

37. Brazil, Ministério de Saúde, Programa Nacional de Doenças Sexualmente Transmissíveis/AIDS, Brasilia, Brazil, official data.

38. Lurie $\mathrm{P}$, Fernandes ME, Hughes V, et al. Socioeconomic status and risk of HIV-1, syphilis and hepatitis B infection among sex workers in Sao Paulo State, Brazil. Instituto Adolfo Lutz Group. AIDS 1995; 9 Suppl 1:S31-37.

39. Valdespino-Gómez JL, García-García ML, del-Río-Chiriboga C, et al. Las enfermedades de transmisión sexual y la epidemia de VIH/SIDA. Salud Publica Mex 1995;37:549-555

40. Uribe-Sals F, del Río Chiriboga C, Conde-Glez CJ, et al. Prevalence, incidence and determinants of syphilis in female commercial sex workers in Mexico City. Sex Transm Dis 1996;23 (2):120-126.

41. Uribe-Salas F, Hernández-Avila $M$, Conde-Glez CJ, et al. Low prevalence of HIV infection and sexually transmitted diseases among female commercial sex 
workers in Mexico City. Am J Public Health 1997; 87:1012-1015.

42. Perez-Bianco R, Santarelli MT. Analysis of a national serological survey for diseases transmitted by blood transfusion. Medicina B Aires 1993;53(6):491-496.

43. Jamaica, Ministry of Health, 1995.

44. Honduras, Ministerio de Salud, Programa Nacional de Enfermedades de Transmisión Sexual, División de Epidemiología, Tegucigalpa, Honduras, official data.

45. Largo P, Metelus-Chalmeau E, Poumerol G. Evaluation of HIV infection, hepatitis $B$ and syphilis among blood donors in Haiti (1986-1990). VII International Conference on AIDS (ICAIDS), 1991. (Abstract No. MC 3119).

46. Brazil, Ministry of Health, official data.

47. Chile, Ministry of Health.

48. Batteiger BE, Fraiz J, Newhall WJ, et al. Association of recurrent chlamydial infection with gonorrhea. J Infect Dis 1989; 159(4):661-669.

49. Espinoza, E, Egger, M, Herrmann, B, Isler, M, Voken, K, Davey Smith, G. STD in Nicaragua: population rate estimates and health seeking behaviour. IX International Conference on AIDS (ICAIDS), 1993. (Abstract No. PO C06 2702).

50. Venegas VS, Villafranca P, Madrid JP, et al. Gonorrhoea and urogenital chlamydial infection in female prostitutes in Tegucigalpa, Honduras. Int J STD AIDS. 1991;2(3):195-199

51. Bernal JN, Martinez MA, Triantafilo VJ, et al. Diagnósticos de enfermedades de transmisión sexual en adolescentes embarazadas chilenas. Rev Chil Obstet Ginecol 1989;54(2):66-70.
52. Levett PN, Taruvinga M, Maheswaran $\mathrm{K}$, et al. Genital tract infections in sexually active women in Barbados. West Indian Med J 1995;44:128

53. Simões JA, Giraldo PC, Ribeiro Filho $\mathrm{AD}$, et al. Prevalência e fatores de risco associados às infecções cérvico-vaginais durante a gestação. Rev Bras Ginecol Obstet 1996;18(6):459-467.

54. Barreto NA, Passos MRI, Gonçalves DD, et al. Isolation of Neisseria gonorrhoeae in female patients in STD sector. International Congress of Sexually Transmitted Diseases. Seville, Spain, 19-22 October 1997. (Abstract P303).

55. Franjola R, Anazco R, Puente R, et al. Trichomonas vaginalis infection in pregnant women and newborn infants. Rev Med Chil 1989;117(2):142-145.

56. Rivera RL, Trenado MQ, Valdez AC, et al. Prevalencia de vaginitis y vaginosis bacteriana: asociación con manifestaciones clínicas de laboratorio y tratamiento. Ginecol Obstet Mex 1996;64: 26-35.

57. Sanchez-Vega JT, Tay-Zavala J, RuizSanchez, et al. Frequency of vaginal trichomoniasis and candidiasis and its relation to the clinical profile. Rev Latinoam Microbiol 1993;35(2):211-216.

58. Panama, Ministry of Health, Epidemiology Unit, 1990

59. Costa Rica, Ministry of Health, 1992.

60. Chile, Ministry of Health, 1993.

61. Jamaica, Ministry of Health, Comprehensive Health Centre, data, 1992.

62. Thejls H, Gnarpe J, Gnarpe H, et al. Expanded gold standard in the diagnosis of Chlamydia trachomatis in a low prevalence population: diagnostic efficacy of tissue culture, direct immunofluores- cence, enzyme immunoassay, PCR and serology. Genitourin Med 1994;70(5): 300-303.

63. Cavaliere MJ, Maeda MY, Shirata NK, et al. Cervico-vaginal Chlamydia trachomatis infection in pregnant adolescent and adult women. Arch Gynecol Obstet 1993;253(4):175-182.

64. Pedreira $\mathrm{W}$, Abreu $\mathrm{H}$, Alvez $\mathrm{M}$, et al. Prevalence of Chlamydia trachomatis (CT) infection in urine samples from asymptomatic men and women by ligase chain reaction (LCR) in comparison with urine leukocyte esterase test (LET). International Congress of Sexually Transmitted Diseases, Seville, Spain, 19-22 October 1997. (Abstract P514).

65. Lowdes CM et al. Chlamydia trachomatis infection in low income women in Rio de Janeiro, Brazil [conference paper]. XI Meeting of the International Society for STD Research. New Orleans, USA. 1995.

66. Echaniz-Aviles G, Calderon-Jaimes E, Carnalla-Barajas N, et al. Prevalence of cervicovaginal infections caused by Chlamydia trachomatis among female population of the city of Cuernavaca, Morelos. Salud Publica Mex 1992;34(3): 301-307.

67. Valdespino-Gómez JL, García-García ML, del-Río-Chiriboga C, et al. Las enfermedades de transmisión sexual y la epidemia de VIH/SIDA. Salud Publica Mex 1995;37:549-555.

68. Herrmann B, Espinoza F, Villegas RR, et al. Genital chlamydial infection among women in Nicaragua: validity of direct fluorescent antibody testing, prevalence, risk factors and clinical manifestations. Genitourin Med 1996;71(1):20-26. 